Journal of Clinical Investigation

Vol. 41, No. 5, 1962

\title{
ANTIBODY TO INTRINSIC FACTOR IN SERUM FROM PATIENTS WITH PERNICIOUS ANEMIA *
}

\author{
By GRAHAM H. JEFFRIES, $\dagger$ DONALD W. HOSKINS AND MARVIN H. SLEISENGER \\ (From the Department of Medicine, New York Hospital-Cornell Medical Center, \\ New York, N. Y.)
}

(Submitted for publication October 30, 1961 ; accepted February 1, 1962)

Schwartz $(1,2)$ and Taylor (3) have suggested that sera from patients with pernicious anemia may contain antibody to intrinsic factor. Both investigators studied the interaction of serum and intrinsic factor in these patients by measuring vita$\min \mathrm{B}_{12}$ absorption after oral test doses of cobalt ${ }^{60}$ labeled vitamin $\mathrm{B}_{12}\left(\mathrm{Co}^{60} \mathrm{~B}_{12}\right)$ mixed with hog intrinsic factor and serum (1-3). In these tests, sera from 40 to 50 per cent of the patients with pernicious anemia inhibited vitamin $\mathrm{B}_{12}$ absorption. This inhibition was observed not only with serum from patients who had received oral therapy with intrinsic factor preparations $(1,2)$ but also with serum from those who were untreated and those who had received only parenteral vitamin $B_{12}(2,3)$. Sera from rabbits which had been immunized with hog intrinsic factor preparations similarly inhibited vitamin $B_{12}$ absorption (4).

Immunological studies by in vitro tanned red cell agglutination techniques have yielded positive agglutination reactions between pernicious anemia sera and tanned red cells coated with hog intrinsic factor $(2,5)$. However, in correlating this in vitro test with in vivo absorption studies, Schwartz (2) reported a 33 per cent incidence of false positive or negative agglutination reactions.

While these observations are consistent with the conclusion that specific antibody to intrinsic factor may be present in the serum of pernicious anemia patients, direct evidence for this is lacking. Although immunological studies in vitro have shown that sera from pernicious anemia patients may react with hog intrinsic factor, a more specific interaction of gamma globulin derived from pernicious anemia serum and purified human intrinsic factor has not been demonstrated.

The experiments described here were carried out in an attempt to define more precisely the in-

* Supported in part by United States Public Health Service Grant C-9386.

$\dagger$ USPHS Research Career Development Awardee. teraction of pernicious anemia sera and human intrinsic factor both in vivo and in vitro. The blocking action of pernicious anemia sera on intrinsic factor activity was demonstrated by vitamin $B_{12}$ absorption tests in which mixtures of serum with intrinsic factor- $\mathrm{Co}^{60} \mathrm{~B}_{12}$ complex were fed to patients with pernicious anemia (2). The in vitro interaction of sera and intrinsic factor was studied by electrophoretic and immunologic techniques. It was found that the pernicious anemia sera that inhibited intrinsic factor activity in absorption studies contained $\gamma$-globulin which combined with human intrinsic factor- $\mathrm{Co}^{60} \mathrm{~B}_{12}$ complex.

\section{Patients}

METHODS

Serum was obtained from 20 normal medical students, 44 patients with pernicious anemia, and 5 patients with atrophic gastritis without pernicious anemia. The diagnosis of pernicious anemia had been established by demonstration of : $a$ ) a macrocytic anemia with megaloblastic bone marrow; $b$ ) gastric achlorhydria on maximal histamine stimulation (6); and $c$ ) subnormal absorption of $\mathrm{Co}^{\infty 0} \mathrm{~B}_{12}$ which was corrected by intrinsic factor. Sera from pernicious anemia patients were obtained before treatment (6 patients) or during maintenance therapy with parenteral injections of vitamin $B_{12}$ (38 patients). Those patients with atrophic gastritis without pernicious anemia exhibited hypochlorhydria on maximal histamine stimulation but absorbed $\mathrm{Co}^{\infty} \mathrm{B}_{12}$ normally.

Twenty patients with pernicious anemia and 1 patient with atrophic gastritis without pernicious anemia (Case 7) were selected for $\mathrm{Co}^{\circ 0} \mathrm{~B}_{12}$ absorption studies with intrinsic factor and serum. This selection was in part influenced by the results of in vitro studies. This study included 10 patients whose serum altered the electrophoretic mobility of an intrinsic factor- $\mathrm{Co}^{00} \mathrm{~B}_{12}$ complex.

\section{Preparation of human intrinsic factor- $\mathrm{Co}^{60} B_{12}$ complex}

Cobalt ${ }^{80}$-labeled vitamin $\mathrm{B}_{12}\left(\mathrm{Co}^{80} \mathrm{~B}_{12}\right),{ }^{1}$ of specific activity $1,000 \mu \mathrm{c}$ per $\mathrm{mg}$, was added to gastric juice freshly collected from normal medical students during histamine stimulation. The concentration of added $\mathrm{Co}^{00} \mathrm{~B}_{12}(250 \mathrm{~m} \mu \mathrm{g}$

1 Obtained from Abbott Laboratories, Oak Ridge, Tenn. 
per $\mathrm{ml}$ of gastric juice) exceeded the binding capacity of the gastric juice so that vitamin $\mathrm{B}_{12}$-binding components were saturated (7). This mixture was dialyzed against water, lyophilized, redissolved in a small volume of 0.03

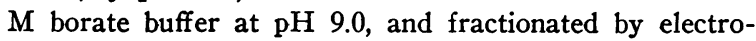
phoresis on starch gel (8).

The anodally migrating zone of bound $\mathrm{Co}^{00} \mathrm{~B}_{12}$ was identified and quantitated by counting $0.5-\mathrm{cm}$ segments of the electrophoretic strip in plastic tubes in a well-type scintillation counter against a $\mathrm{Co}^{\infty}$ standard. Those segments of the electrophoretic strip containing bound $\mathrm{Co}^{20} \mathrm{~B}_{12}$ were homogenized in a small volume of distilled water to give a final concentration of approximately $100 \mathrm{~m} \mu \mathrm{g}$ of vitamin $\mathrm{B}_{12}\left(100 \mathrm{~m} \mu \mathrm{c} \mathrm{Co}^{60} \mathrm{~B}_{12}\right)$ per $\mathrm{ml}$ of homogenate, and stored at $-20^{\circ} \mathrm{C}$.

Studies using this biologically active bound $\mathrm{Co}^{\infty 0} \mathrm{~B}_{12}$ complex (IF-Co ${ }^{80} \mathrm{~B}_{12}$ ) (8), offered three advantages over previous investigations with hog intrinsic factor preparations $(1-3,5)$. 1) Homologous (human) intrinsic factor was utilized; autoantibody, reacting with human intrinsic factor, might not be detected in studies with heterologous intrinsic factor. 2) The sensitivity of tests to demonstrate the interaction of intrinsic factor and serum components is maximal when labeled intrinsic factor alone, IF-Co ${ }^{80} \mathrm{~B}_{12}$, is present in the system. In previous studies with hog mucosal preparations, an excess of unlabeled intrinsic factor would have reduced the sensitivity of the tests (1-3). 3) IF- $\mathrm{Co}^{80} \mathrm{~B}_{12}$ complex prepared by starch gel electrophoresis of human gastric juice (8) is contaminated only by those gastric juice components that have similar electrophoretic mobility. In contrast to this, hog intrinsic factor preparations are electrophoretically heterogeneous (9). Both hog intrinsic factor preparations, and the IF- $\mathrm{Co}^{\circ 0} \mathrm{~B}_{12}$ complex used in this study, however, may contain vitamin $\mathrm{B}_{12}$-binding substances other than intrinsic factor.

\section{Absorption studies}

Vitamin $B_{12}$ absorption tests were carried out on 21 patients (Figure 1) by a modification of the method of Schilling (10). Urine was collected for 48 hours after oral test doses containing $200 \mathrm{~m} \mu \mathrm{g}$ of $\mathrm{Co}^{\circ 0} \mathrm{~B}_{12}(200 \mathrm{~m} \mu \mathrm{c})$. Flushing doses of unlabeled vitamin $B_{12}(1,000 \mu \mathrm{g})$ were injected 1 and 24 hours after the test dose. The 48-hour urinary excretion of $\mathrm{Co}^{00} \mathrm{~B}_{12}$, expressed as a percentage of the administered dose, was greater than 10 per cent in the normal subject.

Successive tests were $a) \mathrm{Co}^{80} \mathrm{~B}_{12}$ alone; $b$ ) IF-Co ${ }^{\infty 0} \mathrm{~B}_{12}$ (containing $200 \mathrm{~m} \mu \mathrm{g}$ vitamin $\mathrm{B}_{12}$ ) ; c) IF $-\mathrm{Co}^{80} \mathrm{~B}_{12}+10 \mathrm{ml}$ of normal serum; and $d$ ) IF- $\mathrm{Co}^{\infty} \mathrm{B}_{12}+10 \mathrm{ml}$ of the patient's own serum. The tests were carried out at weekly intervals in each subject. In half of the patients studied, test $d$ preceded test $c$. In a few patients the absorption studies were confined to tests $a$ and $d$.

\section{In vitro studies on the interaction of sera and} serum protein fractions with $I F-C_{0}{ }^{60} B_{12}$

A. Starch gel electrophoresis. IF- $\mathrm{Co}^{00} \mathrm{~B}_{12}(0.1$ to 0.2 $\mathrm{ml}$ of homogenate containing 10 to $30 \mathrm{~m} \mu \mathrm{g}$ of vitamin $\mathrm{B}_{12}$ ) was mixed with 0.1 or $0.2 \mathrm{ml}$ serum from 20 normal subjects, from 44 patients with pernicious anemia, and from 5 patients with atrophic gastritis without pernicious anemia. This mixture was introduced into a transverse slot in a starch gel electrophoretic strip, and electrophoresis was carried out at $10^{\circ} \mathrm{C}$ for 16 hours at constant voltage of $5 \mathrm{v}$ per $\mathrm{cm}$ (11). In simultaneous control experiments, mixtures of $10 \mathrm{~m} \mu \mathrm{g} \mathrm{Co}{ }^{00} \mathrm{~B}_{12}$ with $0.2 \mathrm{ml}$ serum were separated. The distribution of radioactivity was measured by counting $0.5-\mathrm{cm}$ segments of the gel strip in a well-type scintillation counter.

In a single experiment, varying volumes of serum $(0.025$ to $0.2 \mathrm{ml})$ from Patient 1 were mixed with IF- $\mathrm{Co}^{80} \mathrm{~B}_{12}$, containing $10 \mathrm{~m} \mu \mathrm{g}$ vitamin $\mathrm{B}_{12}$, and were separated by starch gel electrophoresis.

Gamma globulin was prepared from normal and pernicious anemia sera by starch gel electrophoresis (11). At $\mathrm{pH}$ 8.6, the $\gamma_{2}$-globulin fraction migrated cathodally. Segments of starch gel electrophoretic strips containing this protein fraction were mixed with $\mathrm{IF}-\mathrm{Co}^{60} \mathrm{~B}_{12}(10 \mathrm{~m} \mu \mathrm{g}$ vitamin $\mathrm{B}_{12}$ ) by grinding the gel with $\mathrm{IF}-\mathrm{Co}^{80} \mathrm{~B}_{12}$ containing homogenate, and the mixture was again separated electrophoretically.

B. Paper electrophoresis. This method has been used previously to study the interaction of antisera and labeled antigens $(5,12,13)$. In this study mixtures of $0.2 \mathrm{ml}$ serum with IF-C $\mathrm{Co}^{\infty 0} \mathrm{~B}_{12}\left(10 \mathrm{~m} \mu \mathrm{g}\right.$ of vitamin $\left.\mathrm{B}_{12}\right)$ were separated by paper electrophoresis. Fifty $\mu 1$ of this mixture was applied to each paper strip (Whatman no. 3) in a Spinco model $\mathrm{R}$ paper electrophoretic system, and electrophoresis was carried out with veronal buffer ( $\mathrm{pH}$ $8.6,0.075 \mathrm{M}$ ) for 16 hours at $25^{\circ} \mathrm{C}$. The paper strips were oven-dried and bisected longitudinally. One half was stained with amido black; the other half was cut into $1-\mathrm{cm}$ segments. The distribution of radioactivity on the electrophoretic strip was measured by placing these segments in plastic tubes in a well-type scintillation counter.

C. Agar diffusion. These studies were carried out at $25^{\circ} \mathrm{C}$ by the method of Ouchterlony (14), with 1 per cent agar in 0.9 per cent saline. Sera from normal subjects and from pernicious anemia patients were tested against IF- $\mathrm{Co}^{00} \mathrm{~B}_{12}$. In further experiments the agar diffusion plates were modified by incorporating Whatman no. 1 filter paper in the agar gel beneath the diffusion wells. This filter paper, impregnated with agar gel, was separated when diffusion was complete, dried at room temperature, and placed in contact with radiographic film in a cassette. The resulting radioautograph indicated the diffusion of IF- $-\mathrm{Co}^{80} \mathrm{~B}_{12}$ in the gel.

\section{RESULTS}

In vivo absorption studies of the interaction of
normal and pernicious anemia sera with
IF-C ${ }^{60} B_{12}$

The results of the absorption studies carried out on 21 patients are shown in Figure 1. In 9 pa- 

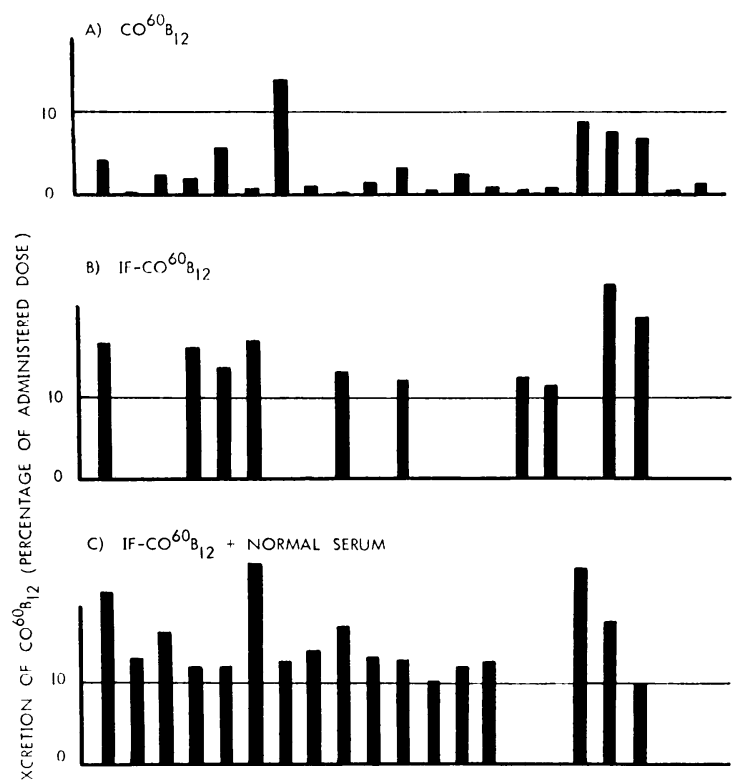

D) IF- $\mathrm{CO}^{6 \mathrm{~B}_{12}}+$ PATIENT'S SERIM

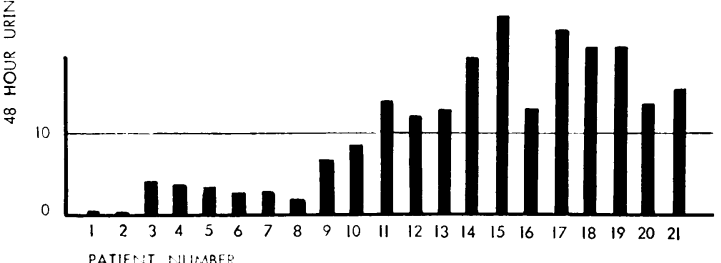

Fig. 1. Urinary excretion of $\mathrm{Co}^{80} \mathrm{~B}_{12}$ in Schilling TESTS ON PERnicious anemia patients. A) $\mathrm{Co}^{60} \mathrm{~B}_{12}$ $\left(200 \mathrm{~m} \mu \mathrm{g}\right.$ vitamin $\mathrm{B}_{12}$ ) without intrinsic factor. B) IF$\mathrm{Co}^{80} \mathrm{~B}_{12}$ (containing $200 \mathrm{~m} \mu \mathrm{g}$ vitamin $\mathrm{B}_{12}$ ). C) $\mathrm{IF}-\mathrm{Co}^{60} \mathrm{~B}_{12}$ with $10 \mathrm{ml}$ of normal serum. D) $I F-\mathrm{Co}^{60} \mathrm{~B}_{12}$ with $10 \mathrm{ml}$ of the patient's own serum.

The 48-hour urinary excretion of $\mathrm{Co}^{60} \mathrm{~B}_{12}$ is expressed as a percentage of the orally administered dose. Patient 7 suffered from atrophic gastritis without pernicious anemia. Tests on Patients 8 and 9 were carried out with 25 and $30 \mathrm{ml}$ of serum, respectively.

tients with pernicious anemia (Cases 1 to 6 and 8 to 10$)$ and in Patient 7 with atrophic gastritis, the oral administration of $10 \mathrm{ml}$ of the patients' own serum with IF- $\mathrm{Co}^{60} \mathrm{~B}_{12}$ inhibited $\mathrm{Co}^{60} \mathrm{~B}_{12}$ absorption. No inhibition was observed when tests with normal serum were carried out in the same patients. In studies on 11 other patients with pernicious anemia (Cases 11 to 21 ) the oral administration of $10 \mathrm{ml}$ of normal serum or of the patients' own serum with $\mathrm{IF}-\mathrm{Co}^{60} \mathrm{~B}_{12}$ did not inhibit $\mathrm{Co}^{60} \mathrm{~B}_{12}$ absorption.
In vitro studies of the interaction of normal and pernicious anemia sera and serum protein fractions with $I F-C 0^{60} B_{12}$

A. Starch gel electrophoresis of serum with $I F-C o^{60} B_{12}$. IF- $\mathrm{Co}^{60} \mathrm{~B}_{12}$ mixed with normal serum, separated anodally on starch gel electrophoresis (Figure 2, A). Electrophoresis of $I F-\mathrm{Co}^{60} \mathrm{~B}_{12}$ with pernicious anemia sera that caused inhibition of $\mathrm{Co}^{60} \mathrm{~B}_{12}$ absorption (inhibitory sera; Cases 1 to 6 and 8 to 10) resulted in the delineation of two zones of radioactivity (Figure 2, B). An anodal zone corresponded to IF-Co ${ }^{60} \mathrm{~B}_{12}$, while the remaining radioactivity was retained in the zone of application. Serum from Patient 7, with atrophic gastritis without pernicious anemia, gave a similar distribution of radioactivity. Sera from 35 pa-

ELECTROPHORETIC MIGRATION OF INTRINSIC FACTOR - $\mathrm{CO}^{60^{6}} \mathrm{~B}_{12}$ COMPLEX WITH PERNICIOUS ANEMIA SERA

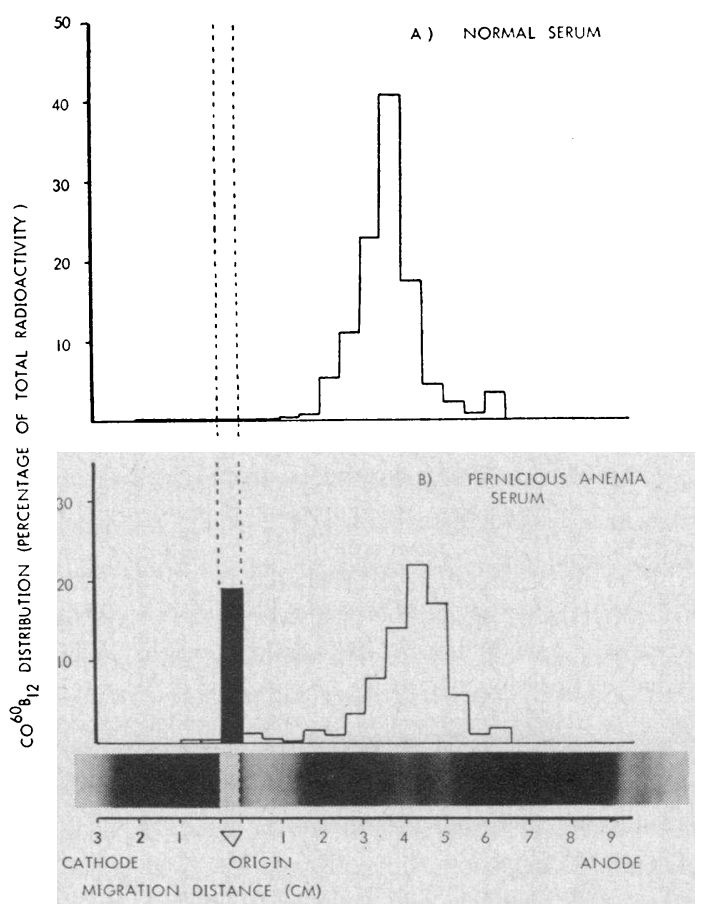

Fig. 2. Starch gel electrophoresis of NORMAL AND pernicious anemia SERA with IF- $\mathrm{Co}^{80} \mathrm{~B}_{12}$. Starch gel electrophoresis of mixtures of serum $(0.2 \mathrm{ml})$ with IF- $\mathrm{Co}^{60} \mathrm{~B}_{12}$ (containing $30 \mathrm{~m} \mu \mathrm{g}$ vitamin $\mathrm{B}_{12}$ ). The distribution of radioactivity and a corresponding electrophoretic strip stained with amide black $10 \mathrm{~B}$ are shown. A) Normal serum. B) Pernicious anemia serum that inhibited vitamin $B_{12}$ absorption (Patient 1 of Figure 1). 
tients with pernicious anemia, including those that did not inhibit $\mathrm{Co}^{60} \mathrm{~B}_{12}$ absorption (Cases 11 to 21 ), caused no alteration in the electrophoretic migration of IF- $\mathrm{Co}^{60} \mathrm{~B}_{12}$, no radioactivity being retained in the zone of application.

B. Starch gel electrophoresis of serum with $\mathrm{Co}^{80} B_{12}$ without intrinsic factor. Starch gel electrophoresis of mixtures of serum with $\mathrm{Co}^{60} \mathrm{~B}_{12}$ separated the radioactivity in a single cathodal peak with a mobility corresponding to that of free (nonprotein-bound) $\mathrm{Co}^{60} \mathrm{~B}_{12}$. The distribution of free $\mathrm{Co}^{60} \mathrm{~B}_{12}$ overlapped that of $\gamma$-globulin. Less than 2 per cent of the added $\mathrm{Co}^{60} \mathrm{~B}_{12}$ (i.e., less than $1 \mathrm{~m} \mu \mathrm{g}$ of vitamin $\mathrm{B}_{12}$ per $\mathrm{ml}$ of serum) migrated anodally or was retained in the zone of application. This distribution was similar for both normal and pernicious anemia sera (Figure 3 ).

C. Starch gel electrophoresis of serum protein fractions with $I F-C o^{60} B_{12}$. Gamma globulin, sep-

ELECTROPHORETIC MIGRATION OF $C 0^{60_{12}}$ WITH PERNICIOUS ANEMIA SERA

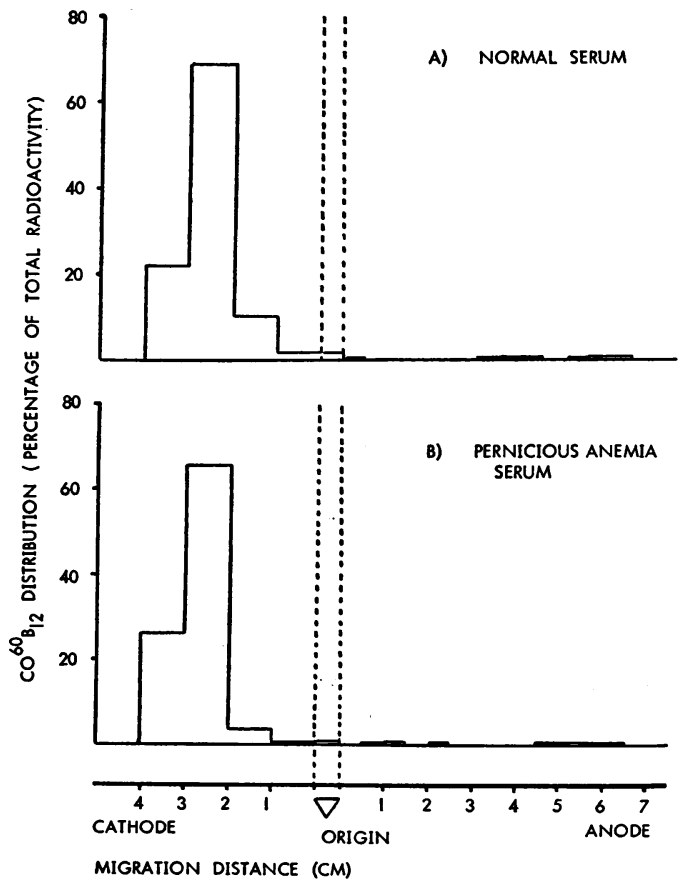

Fig. 3. Starch GEL ELECTROPHORESIS OF NORMAL AND PERNICIOUS ANEMIA SERA WITH $\mathrm{Co}^{60} \mathrm{~B}_{12}$ (WITHOUT INTRINSIC FACTOR). Starch gel electrophoresis of mixtures of serum $(0.2 \mathrm{ml})$ with $\mathrm{Co}^{60} \mathrm{~B}_{12}\left(10 \mathrm{~m} \mu \mathrm{g}\right.$ vitamin $\left.\mathrm{B}_{12}\right)$. The electrophoretic distribution of radioactivity is shown. A) Normal serum. B) Pernicious anemia serum that inhibited vitamin $B_{12}$ absorption (Patient 1 , Figure 1).
ELECTROPHORETIC MIGRATION OF INTRINSIC FACTOR - $\mathrm{CO}^{60} \mathrm{~B}_{12}$ COMPLEX WITH SERUM PROTEIN FRACTIONS

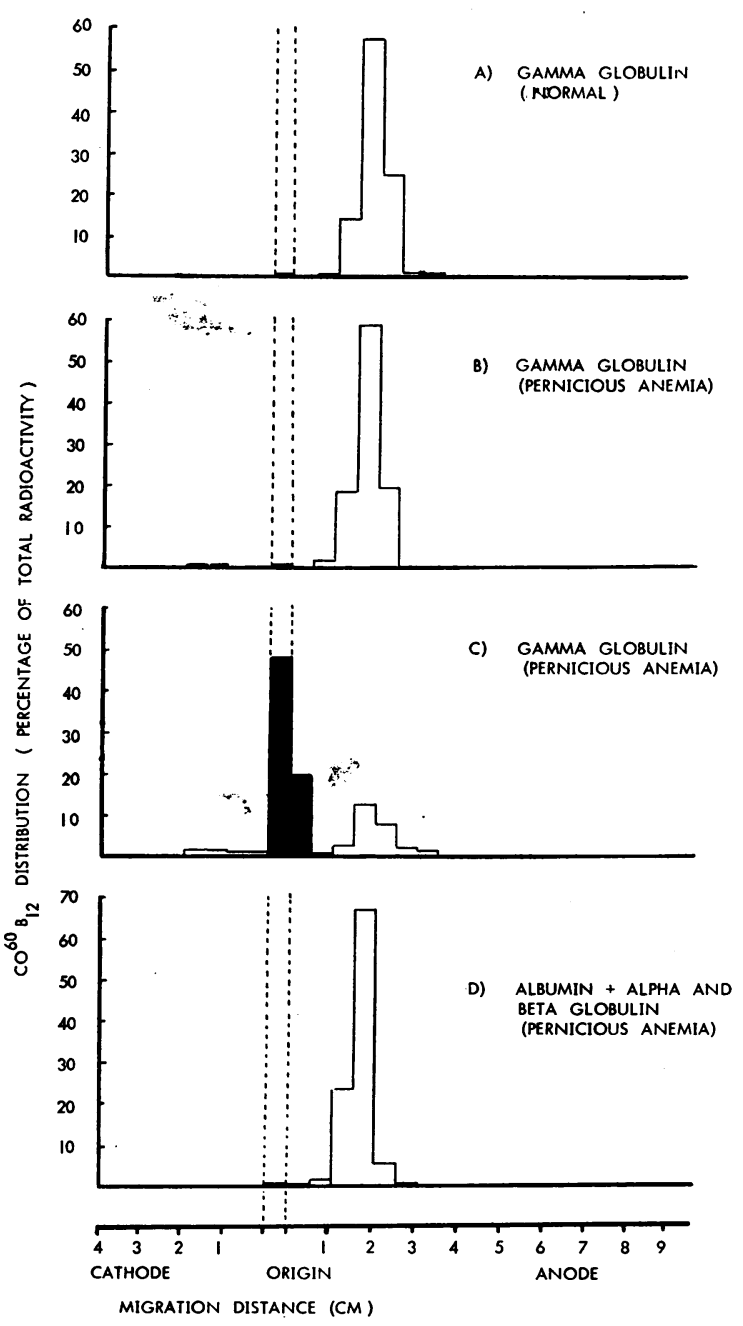

Fig. 4. Starch GeL ELECTROPhoresis of IF-Co ${ }^{60} B_{1:}$ WITH SERUM PROTEIN FRACTIONS FROM NORMAL AND PERNicious ANEMIA SERA. Serum protein fractions were prepared by starch gel electrophoresis. IF-Co ${ }^{\circ 0} \mathrm{~B}_{12}(20$ $\mathrm{m} \mu \mathrm{g}$ vitamin $\mathrm{B}_{12}$ ) was mixed with the serum protein fraction and the mixture was again separated by starch gel electrophoresis. The distribution of radioactivity is plotted. A) $\gamma$-Globulin from $0.2 \mathrm{ml}$ of normal serum. B) $\gamma$-Globulin from $0.2 \mathrm{ml}$ of pernicious anemia serum that did not inhibit $\mathrm{Co}^{\circ 0} \mathrm{~B}_{12}$ absorption (Patient 15). C) $\gamma$-Globulin from $0.2 \mathrm{ml}$ of pernicious anemia serum that inhibited $\mathrm{Co}^{80} \mathrm{~B}_{12}$ absorption (Patient 1). D) $\alpha-, \beta-$ Globulin and albumin from the same pernicious anemia serum as $\mathrm{C}$ ). 


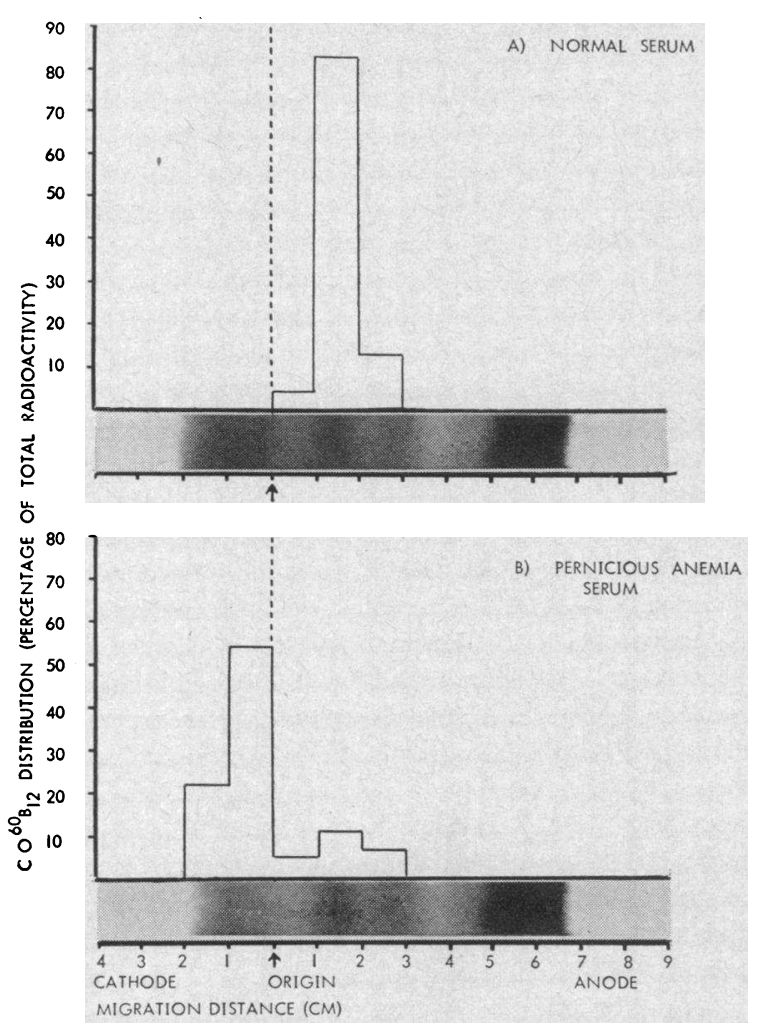

Fig. 5. PAPER electrophoresis OF NORMAL AND PERNicious ANemia SERA With IF- $\mathrm{Co}^{\circ 0} \mathrm{~B}_{12}$. Paper electrophoresis of mixtures of serum $(0.2 \mathrm{ml})$ with $\mathrm{IF}-\mathrm{Co}^{\infty 0} \mathrm{~B}_{12}$ (containing $20 \mathrm{~m} \mu \mathrm{g}$ vitamin $\mathrm{B}_{12}$ ); $50 \mu \mathrm{l}$ of mixture applied to each electrophoretic strip. The distribution of radioactivity and a corresponding electrophoretic strip stained with amide black $10 \mathrm{~B}$ are shown. A) Normal serum. B) Pernicious anemia serum (with inhibitor; Patient 1).

arated by starch gel electrophoresis from those pernicious anemia sera that combined with IF- $\mathrm{Co}^{60} \mathrm{~B}_{12}$ and inhibited $\mathrm{Co}^{60} \mathrm{~B}_{12}$ absorption (Cases 1 to 10 ), altered the electrophoretic migration of IF- $\mathrm{Co}^{60} \mathrm{~B}_{12}$ (Figure 4, C). Radioactivity was retained in the zone of application. The anodally migrating protein fractions of the same sera (albumin and $\alpha$ - and $\beta$-globulins) did not interact with IF- $\mathrm{Co}^{80} \mathrm{~B}_{12}$ to alter its electrophoretic mobility (Figure 4, D). Gamma globulin separated from normal sera and other pernicious anemia sera was similarly unreactive (Figure 4, A and B).

D. Paper electrophoresis of serum with $I F-C o^{60} B_{12}$. IF $-\mathrm{Co}^{60} \mathrm{~B}_{12}$ separated anodally with the electrophoretic mobility of $\beta$-globulin in the presence of normal serum and noninhibitory pernicious anemia serum (Figure 5, A). With inhibitory pernicious anemia serum (Cases 1 to $10)$, IF- $\mathrm{Co}^{60} \mathrm{~B}_{12}$ migrated cathodally with the $\gamma$-globulin fraction (Figure 5, B).

$E$. The interaction of normal and pernicious anemia sera with $I F-C o^{60} B_{12}$ on agar diffusion plates. Diffusion of normal or pernicious anemia sera on agar diffusion plates against IF- $\mathrm{Co}^{60} \mathrm{~B}_{12}$ did not result in the appearance of visible precipitin zones in the agar gel. Radioautographs of filter papers that had been incorporated into the agar diffusion plates beneath the well, however, revealed the presence of linear zones of action between pernicious anemia sera and IF- $\mathrm{Co}^{80} \mathrm{~B}_{12}$. The zone of interaction was related only to those sera that combined with IF- $\mathrm{Co}^{60} \mathrm{~B}_{12}$ in electrophoretic studies (Figure 6).

$F$. The effect of varying serum concentrations on the interaction of inhibitory pernicious anemia serum with $I F-C o^{60} B_{12}$. Figure 7 shows the percentage of radioactivity that was retained in the zone of application when mixtures of IF- $\mathrm{Co}^{60} \mathrm{~B}_{12}$ (containing $10 \mathrm{~m} \mu \mathrm{g}$ of vitamin $\mathrm{B}_{12}$ ) with varying volumes $(0.025$ to $0.2 \mathrm{ml})$ of pernicious anemia

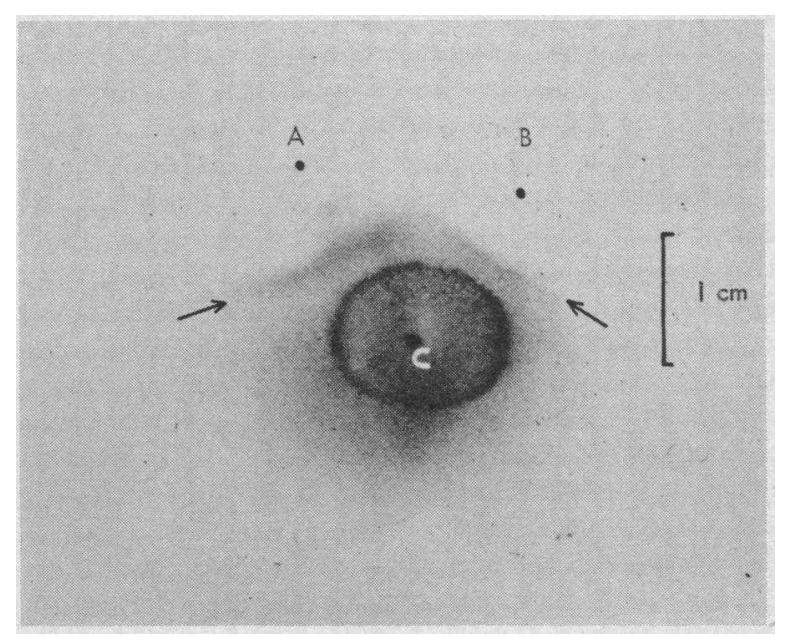

Fig. 6. RADIOAUTOGRAPH OF FILTER PAPER FROM AN Agar diffusion plate. The points $\mathrm{A}, \mathrm{B}$, and $\mathrm{C}$ indicate the center of diffusion wells $0.6 \mathrm{~cm}$ in diameter. Well A contained serum from pernicious anemia Patient 1. Well $\mathrm{B}$ contained serum from pernicious anemia $\mathrm{Pa}$ tient 2. Well $\mathrm{C}$ contained IF- $\mathrm{Co}^{00} \mathrm{~B}_{12}(20 \mathrm{~m} \mu \mathrm{g}$ vitamin $\mathrm{B}_{12}$ ). Diffusion for 3 days at $25^{\circ} \mathrm{C}$; radiographic film exposed for 10 days. Arrows indicate zones of interaction. Zone of radioactivity encircling well $\mathrm{C}$ was an artifact due to the growth of microorganisms. 


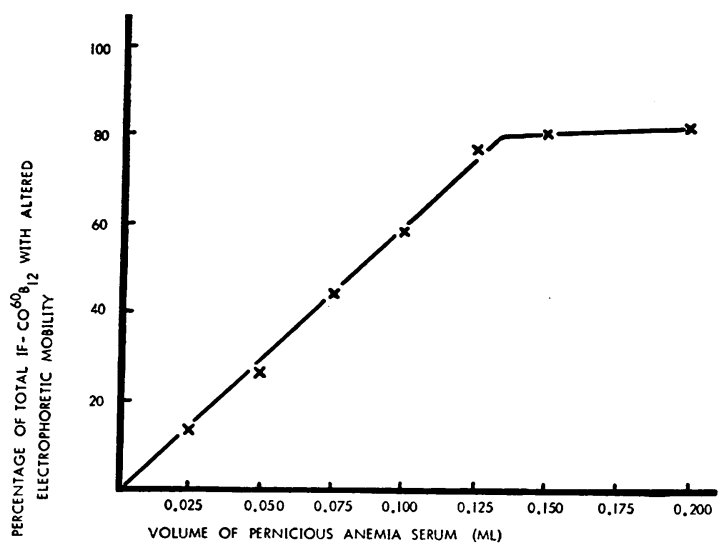

Fig. 7. Starch gel electrophoresis of IF-Co $0^{\infty} \mathrm{B}_{12}$ WITH VARYING VOLUMES OF SERUM. IF-Co ${ }^{\circ 0} \mathrm{~B}_{12}$ (containing $10 \mathrm{~m} \mu \mathrm{g}$ vitamin $\mathrm{B}_{12}$ ) was mixed with 0.025 to 0.20 $\mathrm{ml}$ vol of inhibitory pernicious anemia serum (Patient 1, Figure 1), and the mixtures were separated by starch gel electrophoresis. The percentage of the total radioactivity that remained in the zone of application is plotted for each serum volume.

serum from Patient 1 were separated by starch gel electrophoresis. As the volume of serum in the mixture was increased from 0.025 to $0.125 \mathrm{ml}$, there was a linear increase in the proportion of radioactivity retained in the zone of application. With volumes of serum increasing from 0.125 to $0.2 \mathrm{ml}$, there was no further increase in the proportion of nonmigrating radioactivity. Thus, in the presence of an excess of serum there remained a small proportion of bound $\mathrm{Co}^{60} \mathrm{~B}_{12}$ which migrated anodally. This nonreacting component may represent a bound $\mathrm{Co}^{60} \mathrm{~B}_{12}$ complex without intrinsic factor activity.

The linear increase in nonmigrating radioactivity with increasing amounts of inhibitory serum suggested a nonreversible binding reaction between IF- $\mathrm{Co}^{60} \mathrm{~B}_{12}$ and $\gamma$-globulin. This was tested by adding an excess of unlabeled intrinsic factor to a mixture of inhibitory serum and IF- $\mathrm{Co}^{60} \mathrm{~B}_{12}$. Unlabeled intrinsic factor did not displace IF-Co ${ }^{60} \mathrm{~B}_{12}$ from combination with $\gamma$-globulin (Figure 8).

G. Quantitation of $I F-C^{80} B_{12}$-binding $\gamma$-globulin in inhibitory pernicious anemia sera. The relative concentration of IF- $\mathrm{Co}^{80} \mathrm{~B}_{12}$-binding $\gamma$-globulin in inhibitory pernicious anemia sera was calculated from the proportion of radioactivity retained in the zone of application after starch gel electrophoresis of mixtures of serum with
IF- $-\mathrm{Co}^{60} \mathrm{~B}_{12}$. This is expressed by the equation: $X=Y \times Z$ where $X$ represents serum IF- $\mathrm{Co}^{60} \mathrm{~B}_{12}$ binding ( $\mathrm{m} \mu \mathrm{g}$ vitamin $\mathrm{B}_{12}$ bound as IF- $\mathrm{Co}^{60} \mathrm{~B}_{12}$ by $1 \mathrm{ml}$ serum), $Y$ represents the percentage of radioactivity retained in the application zone, and $Z$ represents the concentration of vitamin $\mathrm{B}_{12}$ in the serum: IF- $\mathrm{Co}^{60} \mathrm{~B}_{12}$ mixture. Values obtained for inhibitory sera, using a single preparation of IF- $\mathrm{Co}^{60} \mathrm{~B}_{12}$, are given in Table I (column 1).

It became apparent during the course of this study that different preparations of IF- $\mathrm{Co}^{60} \mathrm{~B}_{12}$ varied in their content of bound vitamin $B_{12}$. This

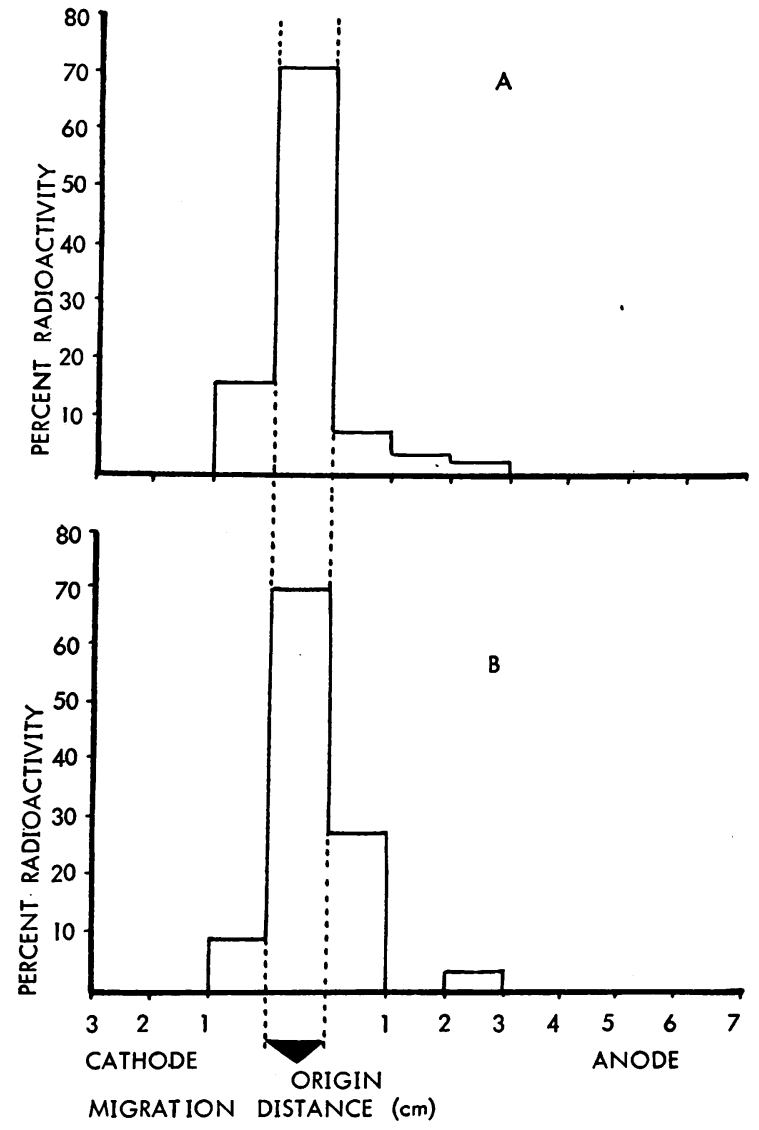

Fig. 8. EFFECT' of ADDING AN EXCESS OF UNLABELED INTRINSIC FACTOR (IF) TO A MIXTURE OF SERUM AND IF-Co ${ }^{\infty} \mathrm{B}_{12}$. Serum $(0.2 \mathrm{ml}$ from Patient 1$)$ was mixed with IF-Co ${ }^{\infty} \mathrm{B}_{12}$ (containing $5 \mathrm{~m} \mu \mathrm{g}$ vitamin $\mathrm{B}_{12}$ ). A) Starch gel electrophoresis of mixture alone; radioactivity remained in or adjacent to the application zone. B) Starch gel electrophoresis of serum: IF- $\mathrm{Co}^{00} \mathrm{~B}_{12}$ mixture with excess of intrinsic factor. IF, separated from $50 \mathrm{mg}$ lyophilized normal gastric juice, was added 10 minutes after mixing serum with IF-Co ${ }^{\infty} \mathrm{B}_{12}$. Electrophoresis was begun 30 minutes later. 
TABLE I

Correlation between inhibition of $\mathrm{Co}^{60} B_{12}$ absorption and IF-Co ${ }^{60} B_{12}$ binding by pernicious anemia sera

\begin{tabular}{|c|c|c|c|}
\hline \multirow[b]{2}{*}{$\begin{array}{c}\text { Patient } \\
\text { no.* }\end{array}$} & 1 & 2 & 3 \\
\hline & $\begin{array}{l}\text { Binding of } \\
\text { IF-Co } \mathrm{Oo}^{60} \mathrm{~B}_{12} \\
\text { by serum } \\
\text { in vitro }\end{array}$ & $\begin{array}{c}\text { Binding of } \\
\text { test dose of } \\
\text { IF-Co60 } \mathrm{B}_{12} \\
(200 \mathrm{~m} \mu \mathrm{g} \\
\left.\mathrm{B}_{12}\right) \text { by } \\
\text { vol of } \\
\text { serum } \\
\text { used in } \\
\text { absorption } \\
\text { test }\end{array}$ & $\begin{array}{l} \\
\text { Inhibition } \\
\text { of Coos } B_{12} \\
\text { absorption } \\
\text { in tests } \\
\text { with pa- } \\
\text { tient's serum }\end{array}$ \\
\hline & $\begin{array}{c}m_{B_{12} / m i} \text { vit. } \\
\text { serum }\end{array}$ & $\%$ & $\%$ \\
\hline $\begin{array}{c}1 \\
2 \\
3 \\
4 \\
5 \\
6 \\
7 \\
8 \dagger \\
9 \ddagger \\
10\end{array}$ & $\begin{array}{r}58.0 \\
28.7 \\
22.5 \\
28.8 \\
31.7 \\
47.0 \\
28.8 \\
7.0 \\
11.3 \\
2.7\end{array}$ & $\begin{array}{r}100 \\
100 \\
100 \\
100 \\
100 \\
100 \\
100 \\
30 \\
56 \\
14\end{array}$ & $\begin{array}{l}98 \\
98 \\
75 \\
69 \\
77 \\
90 \\
79 \\
80 \\
63 \\
35\end{array}$ \\
\hline
\end{tabular}

* Patient numbers correspond to those in Figure 1. †chilling tests were performed on this patient using $25 \mathrm{ml}$ of serum. † Schilling tests were performed on this patient using $30 \mathrm{ml}$ of serum.

variation was due to dissociation of $\mathrm{IF}-\mathrm{Co}^{60} \mathrm{~B}_{12}$ complex with loss of $\mathrm{Co}^{60} \mathrm{~B}_{12}$ during preparative dialysis. The calculated IF- $\mathrm{Co}^{60} \mathrm{~B}_{12}$-binding values of inhibitory sera thus varied with different preparations of $\mathrm{IF}-\mathrm{Co}^{60} \mathrm{~B}_{12}$ (values for serum of $\mathrm{Pa}$ tient 1 from experiments illustrated in Figures 2 and 4 and in Table I, respectively, were $28.5,60$, and $58 \mathrm{~m} \mu \mathrm{g}$ vitamin $\mathrm{B}_{12}$ per $\mathrm{ml}$ of serum.

The action between $\gamma$-globulin of inhibitory sera and IF- $\mathrm{Co}^{60} \mathrm{~B}_{12}$ in vitro would explain the inhibitory effect of these sera in absorption tests if there was an approximate quantitative correlation between these phenomena. Accurate quantitative correlation was not possible because of the variable vitamin $\mathrm{B}_{12}$ content of $\mathrm{IF}-\mathrm{Co}^{80} \mathrm{~B}_{12}$ preparations used in both in vitro tests and absorption studies.

To quantitate the inhibitory activity of pernicious anemia sera on vitamin $B_{12}$ absorption, the urinary excretion of $\mathrm{Co}^{80} \mathrm{~B}_{12}$ in tests with inhibitory sera has been expressed as a percentage of excretion in control tests with normal serum ( $\mathrm{Ta}$ ble I, column 3). The percentage of the absorptive test dose of $I F-\mathrm{Co}^{60} \mathrm{~B}_{12}(200 \mathrm{~m} \mu \mathrm{g}$ vitamin $B_{12}$ ) that would have combined with $\gamma$-globulin in the inhibitory serum, calculated from the serum IF- $\mathrm{Co}^{60} \mathrm{~B}_{12}$-binding value (Table $\mathrm{I}$, column 2 ), was commensurate with the observed inhibition of vitamin $\mathrm{B}_{12}$ absorption (Table $\mathrm{I}$, column 3 ).

\section{DISCUSSION}

The results of vitamin $\mathrm{B}_{12}$ absorption tests utilizing human $\mathrm{IF}-\mathrm{Co}^{60} \mathrm{~B}_{12}$ complex mixed with normal and pernicious anemia sera (Figure 1) confirm the inhibitory effect of some pernicious anemia sera described by $\operatorname{Schwartz}(1,2)$ and Taylor (3). In the present study, inhibition of vitamin $B_{12}$ absorption was demonstrated with $10 \mathrm{ml}$ of pernicious anemia serum. In Schwartz's and Taylor's experiments, however, $50 \mathrm{ml}$ of inhibiting serum was required. This difference probably reflects the presence of an excess of intrinsic factor in the latter studies, rather than a difference in the concentration of serum inhibitor.

Pernicious anemia sera that inhibited vitamin $\mathrm{B}_{12}$ absorption when given orally with $\mathrm{IF}-\mathrm{Co}^{60} \mathrm{~B}_{12}$ to patients with pernicious anemia (inhibitory sera) also altered the electrophoretic migration of $\mathrm{IF}-\mathrm{Co}^{60} \mathrm{~B}_{12}$. On paper electrophoresis, $\mathrm{IF}-\mathrm{Co}^{60} \mathrm{~B}_{12}$, which migrates anodally in normal serum, migrated cathodally with the $\gamma$-globulin of inhibitory sera. A similar observation was made by Lowenstein, Cooper, Brunton and Gartha (5) in paper electrophoretic studies of rabbit immune serum mixed with hog intrinsic factor and $\mathrm{Co}^{80} \mathrm{~B}_{12}$. On starch gel electrophoresis, the IF- $\mathrm{Co}^{60} \mathrm{~B}_{12}$ complex migrated anodally in the presence of normal and noninhibitory pernicious anemia sera, whereas in the presence of inhibitory pernicious anemia sera, the radioactive complex remained in the zone of application.

Gamma globulin, separated from inhibitory pernicious anemia sera by starch gel electrophoresis, was the only serum protein that altered the electrophoretic migration of $I F-\mathrm{Co}^{80} \mathrm{~B}_{12}$. This excludes the possibility that $\mathrm{IF}-\mathrm{Co}^{60} \mathrm{~B}_{12}$ complex might be combining with unsaturated carrier protein in pernicious anemia serum. It has been shown that the serum vitamin $\mathrm{B}_{12}$-binding protein is an $\alpha$-globulin $(15,16)$. Furthermore, the capacity of inhibitory sera to bind IF- $\mathrm{Co}^{60} \mathrm{~B}_{12}$ in the $\gamma$-globulin fraction was considerably in excess of the normal vitamin $\mathrm{B}_{12}$-binding capacity of serum (17). Electrophoretic studies with mixtures of serum and $\mathrm{Co}^{80} \mathrm{~B}_{12}$ in the absence of intrinsic factor also exclude the possibility that free vitamin $\mathrm{B}_{12}$ might be combining with a serum component to form a nonmigrating complex. In these experi- 
ments with free $\mathrm{Co}^{60} \mathrm{~B}_{12}$, radioactivity was not retained in the application zone.

Retention of radioactivity in the zone of application after starch gel electrophoresis of mixtures of $\mathrm{IF}-\mathrm{Co}^{60} \mathrm{~B}_{12}$ with $\gamma$-globulin from inhibitory sera indicates that $\gamma$-globulin binds IF- $\mathrm{Co}^{60} \mathrm{~B}_{12}$ to form a complex which is too large to migrate in the starch gel medium. The formation of a single radioactive zone of interaction of inhibitory pernicious anemia sera and IF- $\mathrm{Co}^{60} \mathrm{~B}_{12}$ in agar diffusion studies, demonstrates that a single complex is formed between IF- $\mathrm{Co}^{60} \mathrm{~B}_{12}$ and $\gamma$-globulin.

On the basis of absorption studies it had been suggested that antibody present in some pernicious anemia sera might inhibit intrinsic factor activity $(2,3)$. This inhibitory effect, observed in our absorption studies, was confined to sera that reacted with IF- $\mathrm{Co}^{60} \mathrm{~B}_{12}$ upon electrophoresis. Furthermore, the amount of $\mathrm{IF}-\mathrm{Co}^{60} \mathrm{~B}_{12}$ that was bound by inhibitory sera in electrophoresis paralleled the inhibitory effect of the same sera in absorption tests. This suggests that the inhibition of vitamin $\mathrm{B}_{12}$ absorption in vivo results from the formation of a complex between IF- $\mathrm{Co}^{60} \mathrm{~B}_{12}$ and $\gamma$-globulin of the inhibitory sera.

The mechanism by which $\gamma$-globulin of inhibitory sera prevents vitamin $B_{12}$ absorption has not been determined. Inhibition occurs, however, only when the blocking $\gamma$-globulin is present in the lumen of the gastrointestinal tract. Patients with inhibitory sera absorbed vitamin $\mathrm{B}_{12}$ normally when IF- $\mathrm{Co}^{60} \mathrm{~B}_{12}$ alone was administered orally. Perhaps binding of $\mathrm{IF}-\mathrm{Co}^{60} \mathrm{~B}_{12}$ to mucosal receptors in the small intestine is prevented by combination with $\gamma$-globulin (2).

The formation of a complex between IF- $\mathrm{Co}^{60} \mathrm{~B}_{12}$ and $\gamma$-globulin of inhibitory pernicious anemia sera is strong evidence of an antigen-antibody reaction. This is supported by immunological studies in the rabbit. Sera of rabbits which had been immunized with hog intrinsic factor preparations not only inhibited intrinsic factor activity in absorption tests (4), but also bound in their $\gamma$-globulin fraction a complex of hog intrinsic factor and $\mathrm{Co}^{60} \mathrm{~B}_{12}(5)$. Proof of the immunological nature of the reaction between $\gamma$-globulin and IF- $\mathrm{Co}^{60} \mathrm{~B}_{12}$ would be the production of a similar human antibody to intrinsic factor by active immunization, and the observation that pernicious anemia patients, with inhibitory sera before immunization, developed an anamnestic response.

An autoimmune phenomenon is suggested by the presence of antibody to intrinsic factor in the serum of pernicious anemia patients who have had no known exposure to exogenous intrinsic factor. The antigenic stimulus may result from the abnormal release of intrinsic factor from the gastric mucosa into the circulation by mucosal injury, or may result from an altered responsiveness of antibody-producing cells to endogenous intrinsic factor. Although this study has more clearly defined the interaction of pernicious anemia sera and intrinsic factor, and has indicated the presence of intrinsic factor antibody in 20 to 30 per cent of those sera, the significance of this antibody in the pathogenesis of atrophic gastritis and pernicious anemia is unclear. Chronic atrophic gastritis may result from the interaction of autoimmune antibodies with antigens in the gastric mucosa. It has recently been reported that injections of homologous or heterologous gastric juices into the dog produce atrophic gastritis (18).

The demonstration of intrinsic factor antibody in the sera of only 20 to 30 per cent of patients with pernicious anemia has not been explained. Intrinsic factor antibody, present at one time in the serum, may disappear when antigenic stimulation ceases (with intrinsic factor secretory failure). If this were the case antibody should be demonstrable more frequently in patients who had more recently developed pernicious anemia, or who suffered from atrophic gastritis but had not yet developed vitamin $B_{12}$ deficiency. In this study only one of five patients with atrophic gastritis without pernicious anemia, and two of six patients with recently diagnosed pernicious anemia, showed antibody in their sera. An alternative explanation may be that atrophic gastritis is the end result of several pathological processes, as yet poorly defined, which do not all result in immunological phenomena.

Patients with pernicious anemia, who have been treated by oral administration of hog intrinsic factor and vitamin $B_{12}$, may become unresponsive to such therapy $(1,5,19)$. Although Schwartz initially considered that such resistance to oral therapy might result from the presence of blocking antibody in the patients' serum, his studies did 
not support this hypothesis $(1,2)$. Lowenstein and co-workers have concluded, however, that there may be an immunological basis for acquired resistance to oral therapy with hog gastric mucosal preparations in pernicious anemia (5); these authors based their conclusion on the results of tanned red cell agglutination tests, correlated with vitamin $B_{12}$ absorption studies. While hog gastric mucosal preparations were shown to react with sera of resistant patients, human gastric juice was nonreactive (5). Patients with acquired resistance to oral hog intrinsic factor absorbed vitamin $\mathrm{B}_{12}$ normally when human gastric juice was administered. Red cells coated with hog pyloric mucosal extract were agglutinated only by serum from these refractory patients, and the agglutination was not inhibited by prior absorption of these sera with human gastric juice. It is apparent therefore that, although the phenomenon of acquired resistance to orally administered hog intrinsic factor may have an immunological basis, it is unrelated to the reaction of autoantibodies with human intrinsic factor.

Further studies with intrinsic factor antibody may not only facilitate the identification of intrinsic factor in vitro, but may also extend our knowledge of the physiologic and pathologic processes that relate to intrinsic factor secretion and vitamin $\mathrm{B}_{12}$ absorption.

\section{SUMMARY}

1. The interaction of sera from pernicious anemia patients and purified human intrinsic factor (IF) $-\mathrm{Co}^{60} \mathrm{~B}_{12}$ complex has been studied by in vivo absorption tests and by in vitro electrophoretic and immunologic methods.

2. Vitamin $B_{12}$ absorption was inhibited when some pernicious anemia sera were given orally with $\mathrm{IF}-\mathrm{Co}^{60} \mathrm{~B}_{12}$ to pernicious anemia patients.

3. Inhibitory pernicious anemia sera reacted with $\mathrm{IF}-\mathrm{Co}^{60} \mathrm{~B}_{12}$ in vitro. These sera altered the electrophoretic mobility of $\mathrm{IF}-\mathrm{Co}^{60} \mathrm{~B}_{12}$.

4. It was shown that $\gamma$-globulin from inhibitory sera combined with IF- $\left.\mathrm{Co}^{60} \mathrm{~B}_{12}: a\right)$ IF- $\mathrm{Co}^{60} \mathrm{~B}_{12}$ migrated with the $\gamma$-globulin fraction of inhibitory sera on paper electrophoresis; $b$ ) $\gamma$-globulin prepared from inhibitory sera altered the electrophoretic mobility of IF- $\mathrm{Co}^{60} \mathrm{~B}_{12}$ on starch gel.

5. A single radioactive zone of action between inhibitory sera and IF- $\mathrm{Co}^{60} \mathrm{~B}_{12}$ was observed in agar diffusion studies.

6. The IF- $\mathrm{Co}^{60} \mathrm{~B}_{12}$ binding by inhibitory pernicious anemia sera was measured by electrophoresis of mixtures of sera with known concentrations of IF- $-\mathrm{Co}^{80} \mathrm{~B}_{12}$. The quantity of IF- $\mathrm{Co}^{60} \mathrm{~B}_{12}$ bound by inhibitory sera was commensurate with the inhibition of vitamin $\mathrm{B}_{12}$ absorption produced by these sera in absorption tests.

7. It is concluded that antibody to human intrinsic factor is present in some sera from patients having pernicious anemia. The significance of this intrinsic factor antibody in relation to the etiology of pernicious anemia is discussed.

\section{ACKNOWLEDGMENTS}

The cooperation of Dr. David V. Becker and the Radioisotope Department of The New York Hospital in making available radioisotope equipment is gratefully acknowledged. The patients presented in this report were studied through the courtesy of Dr. Ralph L. Engle, Jr. We would like to thank Dr. Henry Kunkel for helpful suggestions in the use of immunological techniques, Dr. William Christensen and Dr. David V. Becker for critical review of the manuscript, and $\mathrm{Mr}$. Lloyd Benjamin for technical assistance.

\section{REFERENCES}

1. Schwartz, M. Intrinsic-factor-inhibiting substance in serum of orally treated patients with pernicious anaemia. Lancet 1958, 2, 61.

2. Schwartz, M. Intrinsic factor antibody in serum from patients with pernicious anaemia. Lancet 1960, 2, 1263.

3. Taylor, K. B. Inhibition of intrinsic factor by pernicious anaemia sera. Lancet 1959, 2, 106.

4. Taylor, K. B., and Morton, J. A. An antibody to Castle's intrinsic factor. J. Path. Bact. 1959, 77, 117.

5. Lowenstein, L., Cooper, B. A., Brunton, L., and Gartha, S. An immunologic basis for acquired resistance to oral administration of hog intrinsic factor and vitamin $B_{12}$ in pernicious anemia. $J$. clin. Invest. 1961, 40, 1656.

6. Kay, A. W. Effect of large doses of histamine on gastric secretion of $\mathrm{HCl}$; an augmented histamine test. Brit. med. J. 1953, 2, 77.

7. Jeffries, G. H., Hoskins, D. W., and Sleisenger, M. $\mathrm{H}$. Determination of vitamin $\mathrm{B}_{12}$ binding capacity of gastric juice by starch gel electrophoresis. Clin. Res. 1961, 9, 153.

8. Jeffries, G. H., Smith, F. W., Hoskins, D. W., and Sleisenger, M. H. Fractionation of the non-dialysable components of normal human gastric juice by 
starch gel electrophoresis. Gastroenterology 1961, 41, 467.

9. Glass, G. B. Jerzy. Localization of intrinsic factor and the sites of $\mathrm{B}_{12}$-binding in the paper electrophoresis of human gastric juices and concentrates from hog gastric mucosa. Haemat. latina 1959, 2, 231.

10. Schilling, R. F. Intrinsic factor studies II. The effect of gastric juice on the urinary excretion of radioactivity after the oral administration of radioactive vitamin $B_{12}$. J. Lab. clin. Med. 1953, 42, 860.

11. Pert, J. H., Engle, R. E., Jr., Woods, K. R., and Sleisenger, M. H. Preliminary studies on quantitative zone electrophoresis in starch gel. J. Lab. clin. Med. 1959, 54, 572.

12. Berson, S. A., Yalow, R. S. Bauman, A., Rothschild, M. A., and Newerly, K. Insulin- ${ }^{131}$ metabolism in human subjects: Demonstration of insulin binding globulin in the circulation of insulin treated subjects. J. clin. Invest. 1956, 35, 170.

13. Unger, R. H., Eisentraut, A. M., McCall, M. S., and Madison, L. L. Glucagon antibodies and an immunoassay for glucagon. J. clin. Invest. 1961, 40, 1280.
14. Ouchterlony, O. Antigen-antibody reactions in gels. IV. Types of reactions in coordinated systems of diffusion. Acta path microbiol. scand. 1953, 32, 231.

15. Pitney, W. R., Beard, M. F., and Van Loon, E. J. Observations on the bound form of vitamin $B_{12}$ in human serum. J. biol. Chem. 1954, 207, 143.

16. Mendelsohn, R. S., Watkin, D. M., Horbett, A. P., and Fahey, J. L. Identification of the viamin $\mathrm{B}_{12}-$ binding protein in the serum of normals and of patients with chronic myelocytic leukemia. Blood 1958, 13, 740.

17. Lear, A. A., Harris, J. W., Castle, W. B., and Fleming, E. M. The serum vitamin $B_{12}$ concentration in pernicious anemia. J. Lab. clin. Med. 1954, 44, 715.

18. Schwartz, M., Lous, P., and Meulengracht, E. Reduced effect of heterologous intrinsic factor after prolonged oral treatment in pernicious anaemia. Lancet 1957, 1, 751.

19. Hennes, A. R., Sevelius, H., Llewellyn, T., Woods, A. H., Joel, W., and Wolf, S. Experimental production of atrophic gastritis by a presumably immunologic mechanism (abstract). J. Lab. clin. Med. 1960, 56, 826. 